\title{
LINEAMIENTOS PARA UNA EXÉGESIS ORTODOXA EN EL PANARION DE EPIFANIO DE SALAMIS
}

\author{
CARlos Andrés Blanch \\ Universidad Nacional de Villa María \\ carlosblanch66@hotmail.com
}

Los estudiosos del Cristianismo reconocen dos grandes escuelas de pensamiento -la alejandrina y la antioquena- que delinearon las ideas que servirían de estructura a la teología cristiana. Un punto en discordia entre ellas era la exégesis alegórica de las Escrituras. Epifanio, quien adscribe a la corriente de pensamiento antioquena, condena el método alegórico incluyendo a Orígenes entre las sectas tratadas en su Panarion, a la vez que presenta al lector una propuesta exegética más acorde con la ortodoxia. En nuestro trabajo analizaremos cuáles son los criterios que el autor propone como necesarios para captar el verdadero sentido del texto bíblico.

Exégesis / Alegoría / Epifanio / Origenismo / filología

\section{GUIDELINES FOR AN ORTHODOX EXEGESIS IN PANARION BY EPIPHANIUS FROM SALAMIS}

Christianity scholars recognize two great schools of thought -the Alexandrian and the Antiochian- which delineated the ideas that would serve as a structure for Christian theology. A point in discord between them was the allegorical exegesis of the Scriptures. Epiphanius, who supports the Antiochian trend of thought, condemns the allegorical method and, while presenting the reader with an exegetical proposal more in line with the orthodoxy, he includes Orígen among the sects treated in his Panarion. In our work we will analyze which are the required criteria proposed by the author to capture the true meaning of the biblical text.

Exegesis / Allegory / Epiphanius / Origenism / Philology 


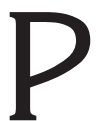

ocas veces durante su historia el cristianismo atravesó un período más crítico que durante el siglo IV. Lo que las persecuciones no pudieron conseguir casi lo logran las disputas entre las distintas facciones al interior de la Iglesia y los ataques de las sectas heterodoxas surgidas de su seno. Valentinianos, arrianos, gnósticos de todas clases, a la vez que pregonaban sus creencias socavaban las bases dogmáticas del cristianismo. Puesto que la defensa de la ortodoxia contra las desviaciones doctrinales requería establecer cuál era la correcta interpretación del texto bíblico -la definición de un dogma es esencialmente un ejercicio de exégesis- un escritor cristiano intentó en su obra, a la vez que combatir la herejía, precisar cuáles eran los elementos esenciales para realizar una exégesis ortodoxa. Nos estamos refiriendo a Epifanio de Salamina.

Se estima que Epifanio nació entre el 310 y el 320 en la aldea de Besanduc, cerca de Gaza. Son pocos los datos fidedignos acerca de su vida aparte de las referencias autobiográficas en una de sus obras-Ancoratus- y las menciones de escritores cristianos como Jerónimo, Basilio de Cesarea y algunos otros de menor relevancia. Se tiene certeza de que fue enviado a Egipto en su juventud para estudiar retórica. Sin embargo, al poco tiempo dejó sus estudios para unirse a una comunidad de monjes con la cual permaneció algunos años. Así, el carácter y el intelecto de Epifanio se formaron bajo la severa influencia del monacato egipcio, firme bastión de la doctrina formulada en el Concilio de Nicea. Tal vez sea por estas circunstancias que en su educación prime el elemento bíblico y devocional -sus refutaciones a ideas heréticas se basan mayormente en citas de la Escritura y otros Padres, no en argumentos filosóficos- en lugar de la típica paideia clásica que constituía el fundamento cultural de otros eminentes pensadores cristianos. Prueba de tal suposición surge a través de la lectura de sus obras, donde las herramientas retóricas, las argumentaciones filosóficas, los razonamientos silogísticos y demás formas del discurso clásico ceden su lugar casi por completo a la autoridad de las Escrituras y la doctrina nicena (Quiroga Puertas, 2013: 2). A pesar de ello, no sería apropiado decir que Epifanio era un hombre inculto según los parámetros de su tiempo, ya que también es posible advertir en sus escritos la soltura con que utiliza los recursos de la filosofía y la retórica clásicas cuando es necesario hacerlo. Más que una cuestión de ignorancia, es una cuestión de preferencia: Epifanio opta por pisar sobre el suelo firme de las Sagradas Escrituras antes que en el terreno que ha dado lugar a tantas herejías, la cultura helenística.

Como antes se dijo, Epifanio rechazaba cualquier creencia que no tuviera su base en lo establecido por el Concilio de Nicea o que estuviera relacionada con doctrinas alejadas de la ortodoxia. Este rechazo se había manifestado en sus tempranos años en Egipto, donde las ideas y prácticas de ciertos grupos gnósticos habían provocado el airado repudio del 
joven cristiano. Cuando entró en contacto con el origenismo este rechazo se extendió también al pensamiento del sabio de Alejandría, cuyas especulaciones acerca de la preexistencia de las almas, la apocatástasis y su perspectiva subordinacionista de la Trinidad, entre otras, mostraban sospechosas similitudes con las interpretaciones gnósticas. Según él, Orígenes era el responsable de muchas de las herejías que azotaban el cristianismo del siglo IV. La importancia que para Epifanio tenía el rebatir al origenismo se evidencia en la extensión que le dedica a este tema en una de sus obras, titulada Panarion.

El Panarion entra en la categoría de los tratados heresiológicos, un género literario común por aquellas épocas. Es también conocido con el título latino de Adversus Haereses, pero en este artículo hemos optado por referirnos a él por su nombre griego a fin de evitar la confusión con la obra de Ireneo. Se considera compuesto a partir de 374 o 375 y concluido tres años más tarde ${ }^{1}$. En esta obra Epifanio plasmó sus propios conocimientos -habiendo vivido en Palestina conocía de primera mano a muchos de los grupos que describe- y recurrió a obras de otros autores, como los Syntagma de Hipólito y el Adversus Haereses de Ireneo, para completar su exposición ${ }^{2}$. El Panarion es un extenso tratado donde su autor describe y refuta ochenta grupos o movimientos religiosos a los que él considera herejías -palabra que en dicha obra debe entenderse en su doble acepción de "facción" y "secta heterodoxa-. Su título, puesto por el mismo autor, indica cuál es el propósito del libro:

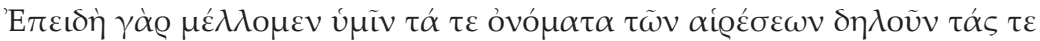

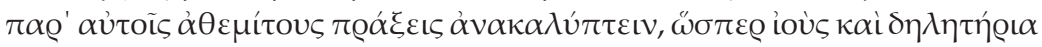

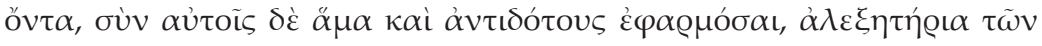

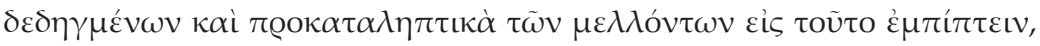

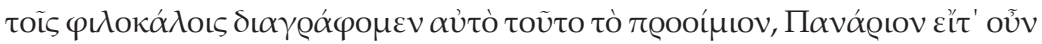

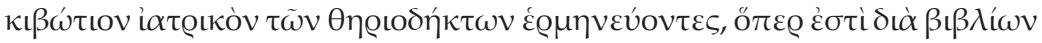

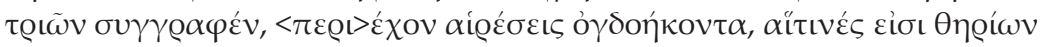

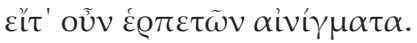

Puesto que estamos a punto de revelaros los nombres de las sectas y desenmascarar sus inicuos hechos como si fueran venenos y cosas tóxicas, y a la vez proporcionar junto con ellos los antídotos, remedios para los que han sido mordidos y preventivos para los que están a punto de caer en ello, escribimos a los que aman la virtud este mismo proemio para explicar el Panarion o "botiquín para los que han sido mordidos por animales venenosos", el cual está escrito en tres libros, <con>teniendo

1 Cf. Epifanio, introducción por Wiluiams, F., (2009: XX).

2 Cf. Epifanio, proemio II, 2; XXXI, 33. 
ochenta sectas, las cuales son [como] insinuaciones veladas de bestias o serpientes ${ }^{3}$.

Las razones dogmáticas que provocaban el rechazo de Epifanio al origenismo ya las hemos mencionado, pero este enfrentamiento tuvo un trasfondo más profundo. En Orígenes y Epifanio se encarnaban dos escuelas, la alejandrina y la antioquena, una de cuyas diferencias evidentes es el aspecto exegético:

Mientras que la escuela de Alejandría creció en su confrontación con el gnosticismo y se desarrolló bajo la influencia de la filosofía platónica, la escuela de Antioquía siguió un camino distinto. Más ligada al aristotelismo y, desde un punto de vista filológico, al hebraísmo rabínico, no constituyó una "escuela" en sentido estricto, aunque es considerada como tal, ya que en varios autores relacionados con Antioquía encontramos el mismo planteamiento exegético y teológico. (PADOVESE, 1996:78.)

La exégesis alegórica de los alejandrinos -muy influenciada por el pensamiento neoplatónico- reconoce un componente eticizante evidente en la interpretación de ciertos pasajes bíblicos como la historia de Agar y Sara, donde la primera es vista como la filosofía pagana, incompleta y subordinada a Sara, representación de la virtud y la verdadera filosofía (Cfr. GRAF Reventlow, 2009: 48-49). La escuela de Antioquía, por su parte, tenía como una de sus preocupaciones el definir y afirmar los dogmas principales de la cristología. Para no caer en errores sobre este aspecto central de la fe era necesario trabajar con un riguroso método exegético. En su refutación al origenismo, Epifanio delineará los principales aspectos y herramientas que deben tenerse en cuenta para lograr esta rigurosidad, no sólo en lo atinente al dogma cristológico sino en la interpretación de todo pasaje bíblico.

La primera consideración que el intérprete debe tener al momento de enfrentarse al texto bíblico es, para nuestro autor, reconocer cuál es el propósito de la exégesis. Si bien este primer punto no puede ser considerado con propiedad una herramienta exegética en sí misma, es una condición previa para toda exégesis y el intérprete de los textos sagrados nunca debe perderlo de vista. En palabras de Teodoro de Mopsuestia, otro miembro de la escuela antioquena: "La tarea del exegeta, creemos, es explicar las palabras que son difíciles de entender para la mayoría (...) También es tarea del intérprete, especialmente aquel que interpreta textos con precisión, que no sólo discuta con autoridad sino que refute a los que se oponen a sus argumentos" (Teodoro de Mopsuestia, 2010: 2). Así, la función de la

3 Epifanio, Proemio I, 1. A menos que se indique lo contrario, los pasajes de esta obra citados en el presente artículo son traducción del autor. 
exégesis es doble: discernir con claridad sobre el sentido del texto bíblico y sostener la ortodoxia contra la herejía.

Como segundo elemento en el proceso exegético, debe realizarse una precisa contextualización del texto a nivel literario e histórico. Epifanio lo dice con claridad en LXIV, 70.3: "Pues a partir del contexto de cada expresión uno puede ver cuál es la verdad de esto". Precisamente una de sus críticas a Orígenes apuntaba a esta falla en el método del alejandrino: "Él se extiende en los textos de las Sagradas Escrituras que se acomodan a sus ideas, aunque no como son o con su interpretación real"4. Mediante un largo extracto de una obra de Metodio, donde éste criticaba las posturas de los origenistas, Epifanio acusa a Orígenes de

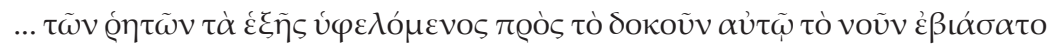

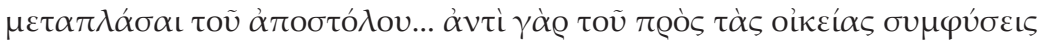

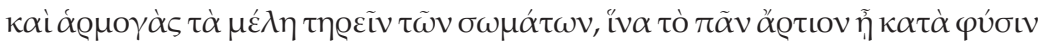

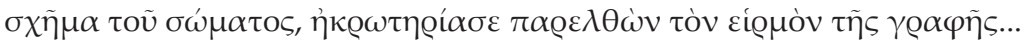

... haber cambiado forzosamente el sentido de los dichos del apóstol, según le pareció conveniente, quitando las siguientes [palabras]... Pues en vez de mantener los miembros del cuerpo junto a sus uniones y articulaciones naturales, para que el conjunto fuera bien proporcionado según la forma natural del cuerpo, al omitirlo mutiló el orden de la Escritura $^{5}$.

El uso de la alegoría por parte del alejandrino desvalorizaba las verdades de fe que pueden alcanzarse a través de la consideración de distintos hechos o personajes históricos contenidos en la Biblia al espiritualizar demasiado el sentido de esos relatos. Para Epifanio, tales hechos, entendidos en su más estricto carácter histórico, encierran verdades y enseñanzas espirituales tan evidentes que no es necesario complicarlos con alegorías. Interpretar en clave alegórica los relatos de sucesos milagrosos pretextando que su sentido más profundo yace, no en el acontecimiento mismo, sino en lo que éste representa implica para él desperdiciar el provecho espiritual que la realidad histórica por sí misma brinda. Incluso aquellos hechos históricos que desafían la razón deben ser aceptados como ocurridos realmente y no como simples metáforas.

La contextualización implica además el reconocimiento de la Escritura como una unidad, en la cual el pasaje tratado se vincula con otros que lo complementan. Este reconocimiento había comenzado ya a principios del siglo II, registrándose en el pensamiento de Clemente de Alejandría,

4 Epifanio, LXIV 4.7.

5 Epifanio, LXIV 50.2-3. 
quien influyó marcadamente en escritores cristianos posteriores. Las Escrituras, consideradas antes como una fuente de argumentos probatorios que podían ser extraídos independientemente de su contexto para apoyar o refutar una postura, comenzaron a ser vistas más bien como un cuerpo cuya coherencia dependía de su unidad (Cfr. SHERIDAN, 2015: 23), y una exégesis ortodoxa imponía esta perspectiva. En función de esta manera de entender la Biblia, Epifanio recurre a citas del Antiguo Testamento para aclarar o apoyar su interpretación de pasajes del Nuevo Testamento y viceversa. Un ejemplo integrador de esta unidad a nivel histórico y literario se registra al comienzo del parágrafo 48 del Panarion, donde Epifanio establece una conexión entre ambos Testamentos por medio de la historia de persecución sufrida por los mártires de Dios:

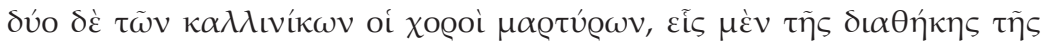

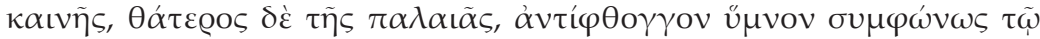

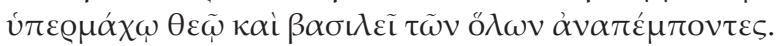

Hay dos coros de mártires victoriosos, uno del Nuevo Testamento y el otro del Viejo, los cuales elevan a una voz un himno antifonal al Dios y Rey protector del universo ${ }^{6}$.

Las relaciones intertextuales abundan en el escrito de Epifanio. Su interpretación de pasajes bíblicos confusos o polémicos se realiza mediante la comparación de éstos con otras citas bíblicas relativas al tema. Por ejemplo, en la refutación a la idea origenista de las túnicas de piel toma como base el relato del Génesis y la complementa y refuerza con pasajes de San Pablo; otras veces sigue el proceso inverso, explicando un versículo del Nuevo Testamento a la luz de otro en el Antiguo 7 . Su aprecio y respeto por los Padres a los que él considera fieles a la ortodoxia también es evidente, y se sirve de sus escritos con el mismo fin.

Mencionamos anteriormente la importancia que Epifanio le concedía al análisis filológico, el cual se constituye en el tercer elemento de su método exegético. Tal como afirma A. Quiroga Puertas, "el rigor religioso que propugnaba Epifanio encontró su plasmación literaria y lingüística en el ejercicio de la crítica filológica" (Quiroga PuERTAS, 2013: 7). Su lectura de los pasajes bíblicos está llena de observaciones sobre el significado de diferentes términos, como la distinción entre $\sigma \tilde{\omega} \mu \alpha$ y $\sigma \alpha ́ \varrho \xi$. Dicho análisis le permite establecer el sentido que el apóstol Pablo confiere a ambos vocablos en sus escritos, en contra de las opiniones de los origenistas:

6 Epifanio, LXIV 48.6.

7 Epifanio, LXIV 38.1-5. 


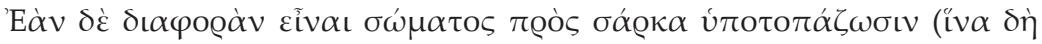

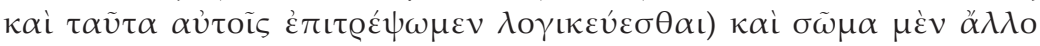

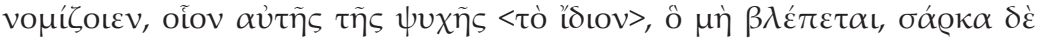

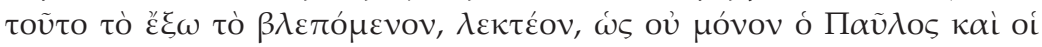

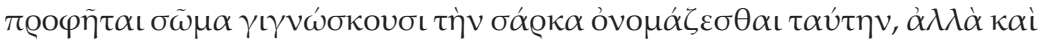

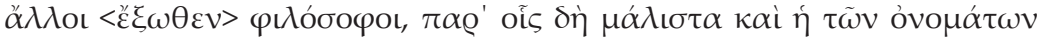

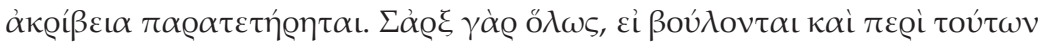

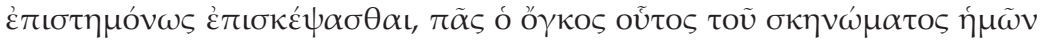

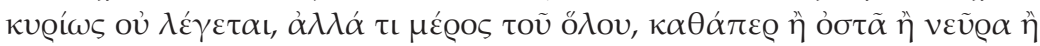

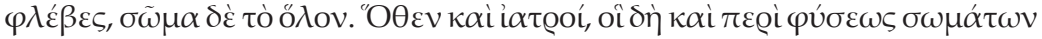

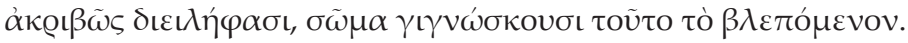

Pero si supusieran que "cuerpo" es diferente de "carne" (para que les permitiéramos también sacar estas conclusiones) y creen que "cuerpo" es algo diferente e invisible, propiedad del alma, por así decir, pero "carne" es el cuerpo externo visible, debemos responder que no son sólo Pablo y los profetas quienes entienden esta carne como "cuerpo", sino también otros filósofos <paganos>, que son los más estrictos acerca de la precisión de los términos. En resumen, si consienten examinar cuidadosamente estos términos, "carne" es la palabra, ciertamente no para la totalidad de nuestro tabernáculo, sino para una parte de la totalidad, como los huesos, nervios y venas. No obstante, la totalidad es "cuerpo". Y los médicos, que reflexionan con cuidado sobre la naturaleza de los cuerpos, entienden que "cuerpo" significa este cuerpo visible ${ }^{8}$.

Precisamente, esta distinción es la que fundamenta su refutación al concepto del cuerpo material como responsable del pecado. Tomando el texto de la Carta de San Pablo a los Romanos, Epifanio aclara que el apóstol "está hablando, no de la carne en sí misma, sino de una vida disoluta [...] Por lo tanto aquí, cuando Pablo dice que lo carnal y aquellos que están en la carne deben morir y no pueden agradar a Dios, no está buscando la destrucción de la carne sino la destrucción del modo de vida carnal"9.

Epifanio criticó duramente lo que él creía era una distorsión de las Escrituras efectuada por el alejandrino. Su admiración por la labor de Orígenes no le permitía consentir lo que él creía era una transgresión al correcto sentido del texto bíblico. En desacuerdo con la interpretación origenista de los Salmos escribió: "A pesar de su interpretación forzada, el salmo [65] no tiene ese significado. Citaré sus verdaderas palabras para mostrar la ficción que es su exposición, puesto que no tienen la intención de enten-

8 Epifanio, LXIV 54.1-2.

9 Epifanio, LXIV 50.9-51.2. 
der las Escrituras correctamente"10. Fue este deficiente método exegético lo que provocó la mayoría de los errores de Orígenes, ya que “(...) él no examinó el pasaje con cuidado. Empleó sus habilidades en cosas que no están exentas de riesgo, y se dedicó a interpretar el salmo de acuerdo con las opiniones de gente vil"11.

Epifanio también criticó el uso que Orígenes hacía de las etimologías, a partir del cual derivaba ideas que se alejaban de la ortodoxia. Así lo hizo con la interpretación origenista de la caída de las almas, basada en una especulación de base etimológica por parte del alejandrino:

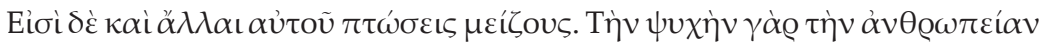

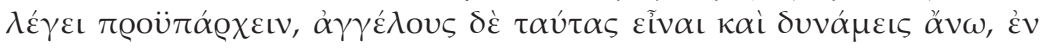

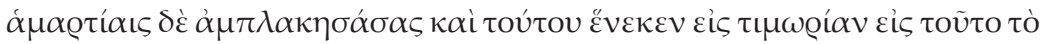

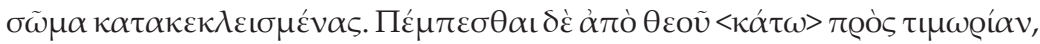

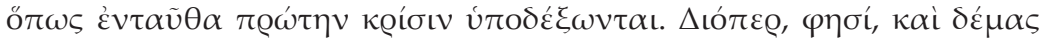

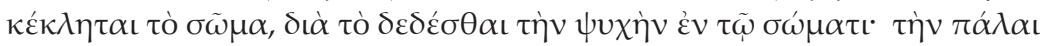

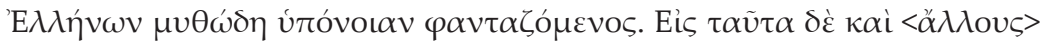

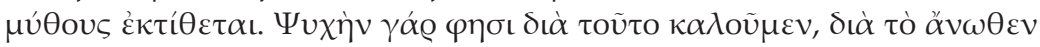
$\varepsilon \dot{\psi} \chi \chi \chi \theta \alpha$ เ.

Pero él también tiene otras fallas mayores. Dice que el alma humana es preexistente, y que las almas son ángeles y potencias celestes, pero cayeron en pecado y por causa de esto fueron encerrados en este cuerpo como castigo. Fueron mandados < abajo> por Dios como castigo, para que sufrieran un primer juicio aquí. Por lo tanto el cuerpo es llamado un "lazo" ( $\delta \varepsilon \dot{\mu} \mu \alpha)$, dice, porque el alma ha sido "atada" ( $\delta \varepsilon \delta \varepsilon ́ \sigma \theta \alpha \mathrm{s})$ al cuerpo; en esta conjetura se evidencia la antigua mentira griega. Y del mismo modo teje <otras> mentiras sobre esto; dice que la llamamos "alma" ( $\psi v \chi \eta ́)$ porque se ha "enfriado" ( $\dot{\psi} v \dot{\chi} \nsucc \propto \alpha \mathrm{\iota})$ al caer ${ }^{12}$.

El antioqueno recurrió a la misma herramienta para exponer ciertos aspectos particulares de algunos pasajes pero lo hizo con una sobriedad y racionalidad destacables. No encontraremos en las obras de Epifanio artificios retóricos o sofísticos. La defensa de la fe requiere de una exégesis filológicamente impecable. Esta exigencia de rigurosidad quedó expresada en el reproche que Epifanio pone en boca de Metodio de Olimpo: "Así, las proposiciones probables, adornadas en aras de la belleza y para dar

10 Epifanio, LXIV 46.12

11 Epifanio, LXIV 47.8.

12 Epifanio, LXIV 4. 5-6.

Argos 40 (2017) ISSN 0325-4194, pp. 47-60 
placer, son a veces mejor consideradas por las masas que los resultados de una investigación precisa"13.

Pero el núcleo de la crítica de Epifanio a Orígenes -y, en general, de la escuela antioquena a la alejandrina- se encuentra en el uso de la alegoría como herramienta hermenéutica. Aunque Epifanio admiraba el trabajo de Orígenes -especialmente sus Hexapla-consideraba que sus especulaciones rayanas con el gnosticismo habían sido la fuente de la cual había surgido el arrianismo ${ }^{14}$. Según él, los errores especulativos de Orígenes habían tenido como punto de partida el uso de la alegoría como herramienta exegética. Sin embargo, no debe suponerse por ello que Epifanio rechazara por completo a la alegoría; al contrario, cuando en el proemio explica la razón del número de sectas tratadas en su libro, él mismo interpreta el texto del Cantar de los Cantares en clave alegórica ${ }^{15}$ :

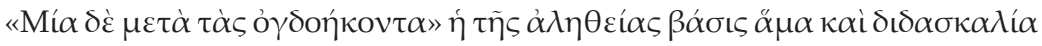

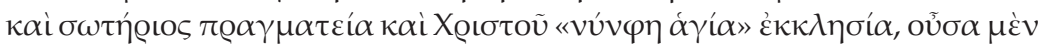

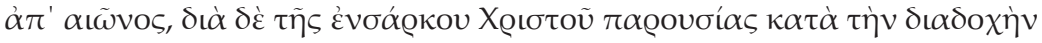

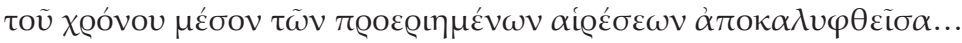

"Una entre ochenta" -junto con el fundamento de la Verdad, la enseñanza, y la obra redentora- es la Iglesia, "la novia santa" de Cristo, que existe desde la eternidad, pero que según la sucesión del tiempo ha sido revelada por la presencia encarnada de Cristo en medio de las antedichas sectas ${ }^{16}$.

Por tanto, en el plano hermenéutico, la crítica de Epifanio a Orígenes se centró más bien en su empleo inmoderado de la alegoría, por utilizarla aun cuando el contexto de las Escrituras exigía realizar una lectura literal, histórica o tipológica. Este exceso surge -según palabras del mismo Orígenes recogidas por Epifanio- del hecho que "la Escritura está llena de enigmas, parábolas, expresiones difíciles y variadas formas de obscuridad, y es complicada para el entendimiento humano"17; para el alejandrino la clave para acceder al conocimiento de las Escrituras en su más profundo sentido sería, pues, el método alegórico. El desacuerdo del autor del Panarion con esta postura quedó plasmado con rotundas palabras:

13 Epifanio, LXIV, 19.5.

14 Cfr. Epifanio, LXIV 4.2; Quiroga Puertas, A., (2013: 2).

15 Cfr. Cantar de los cantares VI, 8-9.

16 Epifanio, Proemio I, 3.

17 Epifanio, LXIV 6, 7. 


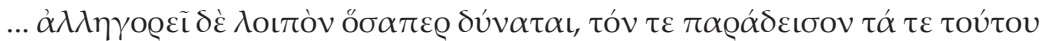

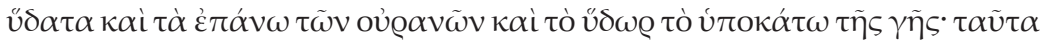

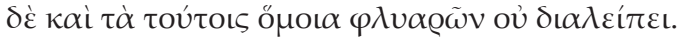

... él da una interpretación alegórica de todo lo que puede: el paraíso, sus aguas, las aguas sobre los cielos, el agua bajo la tierra. No deja de decir estas ridiculeces y otras semejantes ${ }^{18}$.

Poco más adelante, Epifanio se apropia de las palabras de Metodio para criticar no sólo la ineficacia de la interpretación alegórica sino también para reafirmar el sentido literal con el que deben entenderse muchas de las verdades expresadas en la Biblia:

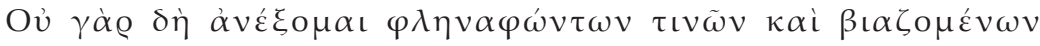

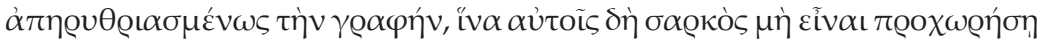

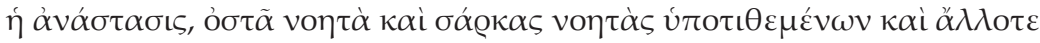

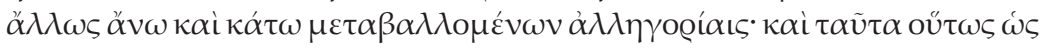

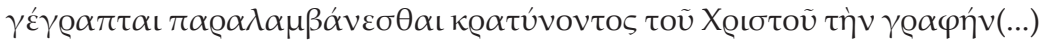

Pues no soportaré a algunos parlanchines que violentan la Escritura sin sonrojarse, sugiriendo que eran "huesos inteligibles" y "carne inteligible", y ponen las cosas de cabeza con alegorías en un pasaje tras otro a fin de decir que la resurrección no es [una resurrección] de la carne. Y Cristo afirma que la Escritura debe ser entendida tal como está escrita $(\ldots)^{19}$

La preferencia de Epifanio por la interpretación literal del texto bíblico se manifiesta en la frecuente expresión "como dice la Escritura". En la mayoría de sus refutaciones a las sectas los argumentos se basan, en última instancia, en pasajes de la Biblia entendidos literalmente. Un ejemplo de ello se encuentra en la refutación del concepto origenista de las túnicas de piel. En su comentario acerca del relato de la caída del hombre, Orígenes planteó una explicación alegórica de las túnicas con que Dios había cubierto a Adán y Eva al expulsarlos del Paraíso. Tales túnicas simbolizaban, para el alejandrino, el componente mortal y pasional con que la naturaleza humana había sido revestida luego de pecar. Epifanio, tomando el texto en su sentido literal, contrapuso firmemente su opinión a la perspectiva origenista:

18 Epifanio, LXIV 4, 11.

19 Epifanio, LXIV 31, 3-4.

Argos 40 (2017) ISSN 0325-4194, pp. 47-60 


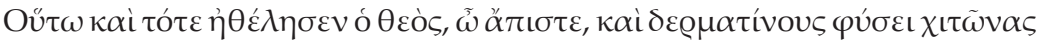

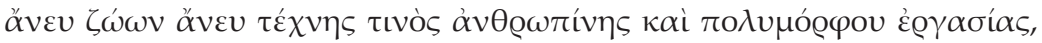

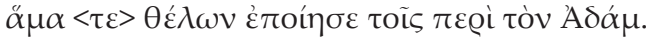

Y también en tiempos de Adán, ¡oh, incrédulo!, Dios quiso, e hizo, verdaderas túnicas de piel sin animales, sin factura de hombre ni de ninguna de las varias clases de trabajo humano $(\ldots)^{20}$

Mientras la exégesis alejandrina estaba permeada por conceptos tomados del neoplatonismo, la escuela antioquena apostó por otros recursos exegéticos al considerar que la alegoría se identificaba con una interpretación filosófica helenista y, por ende, de cuño pagano. De acuerdo con esta postura, Epifanio también consideraba que existen alternativas más apropiadas para comprender un texto de manera ortodoxa, las cuales se constituyen en el cuarto aspecto a tener en cuenta.

La primera de ellas es la tipología. Un tipo bíblico es un elemento o personaje del Antiguo Testamento "que anuncian en figura la economía del Evangelio y del Reino futuro" (DANIÉLou, 1966: 23). A cada tipo le corresponde a su vez un antitipo, es decir, un elemento cuya realidad histórica encuentra puntos de analogía con el primero. Si no existe esta correlación es posible establecer un aspecto simbólico entre figuras, pero no tipológico. Los escritores evangélicos y neotestamentarios hacen abundante uso de la tipología; como ejemplo, puede citarse a San Pablo cuando presenta a Cristo como el segundo Adán (Cfr. Epístola de San Pablo a los Romanos V, 14.) El propio Diodoro de Tarso -"fundador" de la escuela de An-

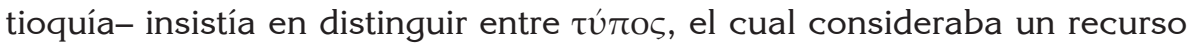
exegético legítimo, y $\alpha \lambda \lambda \lambda \gamma \gamma$ óí $\alpha$, la que rechazó por su identificación con las ideas filonianas y neoplatónicas. Epifanio también empleó la tipología como apoyo a sus argumentaciones. Discutiendo con los origenistas acerca de la realidad material de la resurrección estableció una doble relación tipológica: Cristo mismo se presenta como antitipo del Templo, y a su vez Epifanio vincula la resurrección de Cristo como tipo de nuestra resurrección:

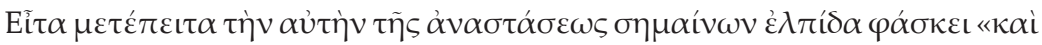

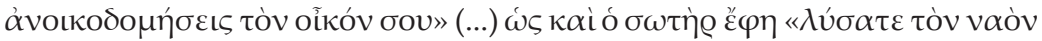

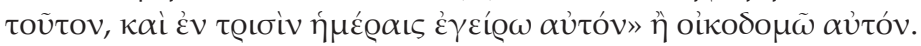

Y luego dice a continuación, dando a entender la misma esperanza de la resurrección: "Y reconstruirás tu casa" (...) Y el Salvador dijo "Destruid este templo, y en tres días lo levantaré", o lo edificaré ${ }^{21}$.

20 Epifanio, LXIV 66.5.

21 Epifanio, XLIV 71.4-5.

Argos 40 (2017) ISSN 0325-4194, pp. 47-60 
Para Epifanio, la exégesis tipológica obtiene un fundamento más firme que la alegórica, al basarse en hechos y personajes históricos. Sin embargo, existen en las Escrituras innumerables figuras, como Noé y el Arca o David triunfante sobre Goliat, que no registran un antitipo en el Nuevo Testamento; no obstante, son figuras que encierran un profundo significado y de las cuales pueden extraerse valiosas enseñanzas. Son figuras hiperbólicas, es decir, referencias cuyo sentido va más allá de lo que está comprendido por el contexto histórico y literario. Aunque distintas de las tipológicas, estas figuras, correctamente interpretadas, son una útil herramienta exegética. Estos recursos le permitieron a Epifanio evitar muchos de los riesgos de la interpretación alegórica.

La segunda alternativa a la alegoría es la $\alpha v \alpha \lambda$ oүía. Para Epifanio, la analogía permite establecer una correspondencia lógica entre la representación y el objeto, en estrecha relación con la forma parabólica usada en los Evangelios. En la refutación de las ideas origenistas sobre la resurrección del cuerpo Epifanio recurrió a varias analogías para explicar cómo el cuerpo físico puede ser realmente resucitado, como la de la semilla que germina y se convierte en planta ${ }^{22}$. Inclusive expresa por medio de una analogía el carácter de quienes se valen de artificios y engaños para torcer la verdad y seducir a los ingenuos e ignorantes:

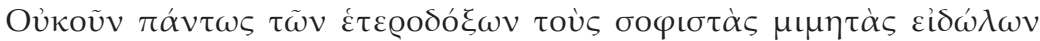

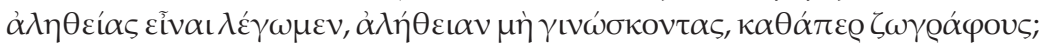

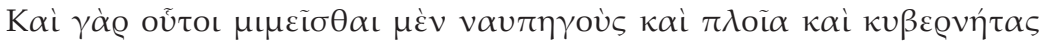

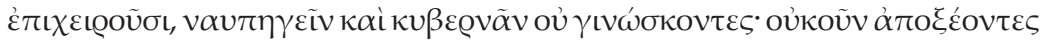

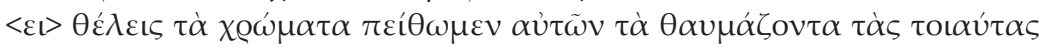

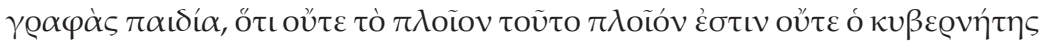

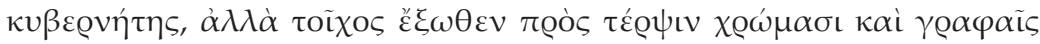

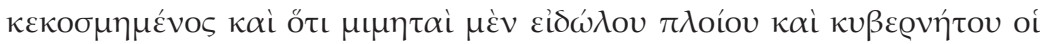

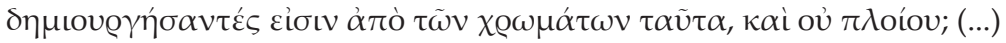

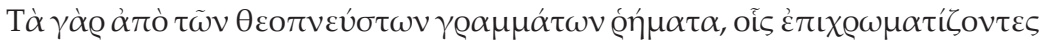

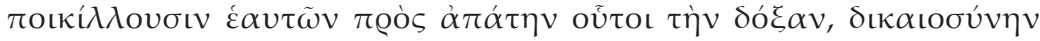

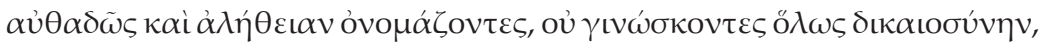

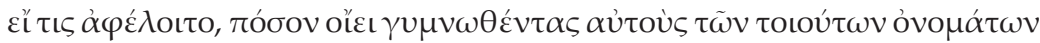
$\chi \lambda \varepsilon v \alpha \sigma \theta \eta \dot{\sigma \varepsilon \sigma \theta \alpha \iota ; ~}$

¿No diremos, entonces, que los sofistas que tienen falsas creencias no son más que imitadores de imágenes de la verdad quienes, como pintores, no conocen la verdad? Pues los pintores tratan de imitar barcos, botes y pilotos y no saben construirlos o pilotearlos. Pues bien, rasgando la pintura, convencemos a aquellos que, como niños, admiran tales retratos,

22 Epifanio, LXIV 16.7-9.

Argos 40 (2017) ISSN 0325-4194, pp. 47-60 
de que ni ese barco es un barco, ni ese piloto es un piloto, sino un muro con su superficie decorada con pintura e imágenes en aras del placer, y los artistas que las hicieron con sus pinturas son imitadores, no de un barco sino de la imagen de un barco y un piloto? (...)

Si alguno removiera [la pintura de] las inspiradas palabras de las Escrituras, a las cuales esta gente ha embadurnado en su opinión con brillantes colores para su propio engaño, llamándolo arrogantemente "justicia" y "verdad" cuando no saben nada acerca de la justicia, ¿¿cuán despreciativamente piensas que serían tratados si fueran despojadas de tales nombres? ${ }^{23}$

Epifanio utiliza la analogía porque -afirma- las realidades espirituales más sublimes no pueden conocerse por experiencia o por razonamiento; a pesar de ello, Dios entiende las limitaciones de nuestro intelecto y nos revela sus verdades de modo analógico. Al decir esto, el antioqueno reconoce que hay una correspondencia no sólo lógica sino real entre la figura y lo que ésta representa. Por ello, asume que la analogía es una herramienta mucho más válida para captar el sentido de un pasaje bíblico que la alegoría, ya que ésta última carece de dicho anclaje en la lógica y la realidad y está más ligada a la pura especulación.

La exégesis alegórica, usada preferentemente por la escuela de Alejandría, brindaba muchas más posibilidades especulativas en el plano interpretativo. Sin embargo, lo que los alejandrinos podrían haber considerado una ventaja fue visto negativamente por Epifanio. La alegoría no ofrecía la rigurosidad que surge de un análisis filológico más estricto que los realizados por Orígenes; al carecer de este fundamento, sus interpretaciones daban pie a doctrinas gnósticas que se alejaban de la ortodoxia. De esta manera, las herramientas propuestas por Epifanio para una correcta exégesis bíblica muestran su interés en establecer un método exegético más preciso y fidedigno en una época en la cual los estándares críticos estaban aún muy lejos de alcanzar la objetividad.

23 Epifanio, LXIV 20.5-6. 


\section{Fuentes primarias}

Epifanio De Salamina, Adversus Haereses, Migne Patrologia Graeca 041.

Teodoro De Mopsuestia, Comentario al Evangelio de Juan, en Ancient Christian Texts, translated by Marco Conti, Inter Varsity Press, Illinois, 2010.

\section{Bibliografía crítica}

Daniélou, J. (1966) Tipología bíblica. Sus orígenes, Ediciones Paulinas, Buenos Aires.

Graf Reventlow, H. (2009) History of Biblical Interpretation. Volume 2: From late Antiquity to the End of Middle Ages, Society of Biblical Literature, Atlanta.

PAdovese, L. (1996) Introducción a la teología patrística, Verbo Divino, Navarra.

Quiroga Puertas, A. (2013) "Léxico y ortodoxia religiosa en el Panarion de Epifanio de Salamis", Ilu, Revista de Ciencias de las Religiones, Madrid, Universidad Complutense, Servicio de Publicaciones XXIV, 2013, pp 13-19.

Sheridan, M. (2015) Language for God in Patristic Tradition. Wrestling with Biblical Anthropomorphism, InterVarsity Press, Illinois.

WiLliams, F. (2009) The Panarion of Epiphanius de Salamis, Book I, translated by Frank Williams, Nag Hammadi and Manichaean studies, volume 79, Brill, Leiden.

_ (2013) The Panarion of Epiphanius de Salamis, Books II and III. De Fide, Second, revised edition, translated by Frank Williams, Nag Hammadi and Manichaean studies, volume 79, Brill, Leiden.

Fecha de recepción: 23-07-2017

Fecha de aceptación: 07-02-2018 